the whole, subject to amendments. 11.07.2019. URL: http://w1.c1.rada.gov.ua/pls/radan_gs09/ns_arh_golos? g_id=2898708\&n_skl=8 (in Ukrainian)

Roll-call vote on the draft Resolution on the inclusion in the agenda of the Second Session of the Verkhovna Rada of Ukraine of the ninth convocation of the Bill on Amendments to Articles 76 and 77 of the Constitution of Ukraine (on reduction of the constitutional composition of the Verkhovna Rada of Ukraine and consolidation of the proportional electoral system) and its submission to the Constitutional Court of Ukraine (No. 1017 / P) - as a whole. 03.09.2019. URL: http://w1.c1.rada.gov.ua/pls/radan_gs09/ ns_golos?g_id=251 (in Ukrainian)

Code of Good Practice in Electoral Matters 2002. URL:https://www.venice.coe.int/webforms/ documents/default.aspx?pdffile $=$ CDL-AD (2002)023rev2-cor-e

Law of Ukraine "On Amendments to Certain Legislative Acts of Ukraine on Preventing and
Combating Political Corruption” № 731-VIII from 15.10.2015. URL: https://zakon.rada.gov.ua/ laws/show/731-19 (in Ukrainian)

The results of the 2012 parliamentary elections. URL: $\quad$ https://cvk.gov.ua/pls/vnd2012/wp611ad94. html?PT001F01=900 (in Ukrainian)

The results of the 2014 parliamentary elections. URL: https://web.archive.org/web/20141127052319/ http://www.cvk.gov.ua:80/pls/vnd2014/wp611?PT001 F01 $=910$ (in Ukrainian) URL:

The results of the 2019 parliamentary elections.

https://www.cvk.gov.ua/pls/vnd2019/wp611pt001f01= 919.html (in Ukrainian)

"How updated was the Verkhovna Rada after the elections?" Laboratory of Legislative Initiatives. URL: https://www.facebook.com/100489156697424/posts/23 63999713679679/ (in Ukrainian)
Lyubov Pivneva

Professor, Dr.Sc. in Political Science, V.N. Karazin Kharkiv National University, 4, Svoboda Sq., Kharkiv, 61022, lyubovpivneva2@gmail.com, https://orcid.org/0000-0002-1592-4746

\title{
POLITICAL PORTRAIT OF A UNIVERSITY PROFESSOR: SOME TENDENCIES IN THE GLOBALIZATION ERA
}

The article explores political and social characteristics of such a professional layer in higher education as university professoriate. Some changes in roles and political attitudes of a university professor are traced during the last decades of globalization in various types of states, Ukraine included. The author states that university professoriate constitutes the elite of higher educational establishments and exerts considerable impact not only onthe development of scientific knowledge and education but on power relations in society as well. By way of illustration, an imaginative simulated portrait of a professor with singling out the main characteristic features is provided. The articletraces the impact of introduction ofmarket relations onprofessorial activity at higher educational establishments and characterizes it on the basis of general tendencies of development at universities and in society. An imaginative simulated portrait of a professor with description of the main characteristics is suggested. The introduction of market relations into professorial activity at higher educational establishments is investigated and characterized on the basis of general tendencies of development at universities and in society.

It is noted that the core of professor's political portrait stems from political orientations and values which in their turn affect the formation of public opinion. The author points out that the main reasons of political preferences of professors are rooted in a character of a political regime, forms of government, existence or banning democratic rights and freedoms, changeability of ideologies in this or that country, etc. At the same time examples that illustrate different approaches of scholars to

(C) Pivneva L., 2019. 
political activity within and outside the campus are given. Inparticular, the main structural elements of a simulated university's professor portrait in the context of political views, orientations,

behaviorare referred.As they are a little studied, it is important for political scientists to pay attention to researchingpolitical attitudes of professoriate as this professional layer exerts great influence on young generation.

Keywords: university professor, globalization, higher educational establishments, political portrait, political views and political behavior of academics, public service.

\author{
Півнева Любов Миколаївна, \\ професор, д. політ.н., \\ Харківський національний \\ університет імені В.Н. Каразіна, \\ майдан Свободи, 4, Харків, 61022, \\ lyubovpivneva2@gmail.com, \\ https://orcid.org/0000-0002-1592-4746
}

\title{
ПОЛІТИЧНИЙ ПОРТРЕТ УНІВЕРСИТЕТСЬКОГО ПРОФЕСОРА: ДЕЯКІ ТЕНДЕНЦІї В ЕПОХУ ГЛОБАЛІЗАЦЇ̈
}

Досліджуються політичні та соиіальні особливості такого професійного прошарку у вищій освіті, як університетська професура. Деякі зміни в ролях $і$ політичних відносинах професора університету простежено протягом минулих десятиліть розвитку глобалізації в різних типах держав, включаючи Украӥну. Стверджується, щи університетська професура складає еліту вищих навчальних закладів $і$ здійснює значний вплив не лише на розвиток наукових знань та освіту, а й на владні відносини у суспільстві. Запропонований образний модельований портрет професора з виділенням головних особливостей.Досліджується впровадження ринкових відносин у професорську діяльність у вищих навчальних закладах, яка характеризується на основі загальних тенденцій розвитку університетів і суспільства.

Відзначається, щฺо в основі політичного портрету професора лежать політичні орієнтації та цінності, які своєю чергою зачіпають формування суспільної думки. Вказується, щуо головні причини політичних уподобань професорів полягають у характері політичного режиму, формах правління, наявності чи відсутності демократичних прав $i$ свобод, мінливості ідеологій у тій чи іншій краӥні тощо. Водночас наводяться приклади, які ілюструють різні підходи вчених до політичної діяльності в межах і поза кампусу. Зокрема даються посилання на основні структурні елементи моделі портрета професора університету, його політичні погляди, орієнтації, поведінки. Оскільки вони не до кіния вивчені, звертається увага політологів на важливість дослідження політичних відносин, характерних для професоріату, тому щчо цей професійний шар дуже впливає на молоде покоління.

Ключові слова: університетський професор, глобалізащія, вищі навчальні заклади, політичний портрет, політичні погляди і політична поведінка вчених, служіння суспільству

\footnotetext{
Пивнева Любовь Николаевна профессор, д. полит.н., Харьковский национальный университет имени В.Н. Каразина, площадь Свободы, 4, Харьков, 61022, lyubovpivneva2@gmail.com, https://orcid.org/0000-0002-1592-4746
} 


\section{ПОЛИТИЧЕСКИЙ ПОРТРЕТ УНИВЕРСИТЕТСКОГО ПРОФЕССОРА: НЕКОТОРЫЕ ТЕНДЕНЦИИ В ЭПОХУ ГЛОБАЛИЗАЦИИ}

Исследуются политические и социальные особенности такого профессионального слоя в высшем образовании, как университетская профессура. Некоторые изменения в ролях и политических отношениях профессора университета прослежены в течение прошлых десятилетий развития глобализации в различных типах государств, включая Украину. Утверждается, что университетская профессура составляет элиту высших учебных заведений и оказывает значительное воздействие не только на развитие научных знаний и образование, но и на властные отношения в обществе. Предложен образный моделируемый портрет профессора с выделением главных особенностей. Исследуется внедрение рыночных отношений в профессорскую деятельность в высших учебных заведениях, оно характеризуется на основе общих тенденций развития университетов и общества.

Отмечается, что в основе политического портрета профессора лежат политические ориентации и ценности, которые в свою очередь затрагивают формирование общественного мнения. Указывается, что главные причины политических предпочтений профессоров заключены в характере политического режима, формах правления, наличии или отсутствии демократических прав и свобод, изменчивости идеологий в той или иной стране и т.д. В то же время даются примеры, которые иллюстрируют разные подходы ученых к политической деятельности в пределах и вне кампуса.В частности даются ссылки на основные структурные элементы моделируемого портрета профессора университета, его политические взгляды, ориентации, поведение. Так как они не до конца изучены, обращается внимание политологов на важность исследования политических отношений профессориата, поскольку этот профессиональный слой оказывает большое влияние на молодое поколение.

Ключевые слова: университетский профессор, глобализация, высшие учебные заведения, политический портрет, политические взгляды и политическое поведение ученых, служение обществу.

The study of global picture of political culture of society needs to address the challenge of understanding political and cultural orientationsand values within institutional context of higher education. Particularly important are the attempts to characterize the individuals in higher education known as university professoriate. They belong to the elite of higher educational establishments and exert considerable impact not only on scientific knowledge but on the power relations in society as well. Scientific and political experience of professoriate, its political views and orientations contribute to young citizens' upbringing and attitudes formation.

Specifics of this social and professional group, its education, mobility level, innovative approaches, relations with a political system give a chance to allocate the major identification lines, which will allow us to define professors' interest towards politics, manifestations of their political beliefs in public. For this it is expedient to simulate a political portrait of university professorate on the basis of transformations in professional roles in globalized era.

Globalization deteriorated power relations, boosted scientific and technical progress and brought to life the transformation of the global higher education system. It introduced market mechanisms in the form of entrepreneurial relations and privatization and contributed to massification of higher education which led to increase of students. Globalization affected different social classes and strata of society, making university professoriate subjective to new tendencies of modernization in globalized era. That's why this layer of elite became the focus of attention of many scientists.

The portrait of a university professor in different states was studied mostly through the prism of universities' role in globalized era. D. Bok, G.A. Jones, P. L. McCarney, M.L. Skolnik, N. Stromquist, H. Etzkowitz, R. Viale, etc., investigated political aspects of internationalization and globalization in higher education with university growth, development of entrepreneurial relations in education, systematic efforts of university's professors to research endeavors, and their experimenting with the methods of instruction, etc. The status and possibilities of university professors to accommodate to society changes were deeply explored by such writers as P.G. Altbach, L.Reisberg, L.E. Rumbley, M. Yudkevich, G. Androushchak, I. F. Pacheco, etc.

In their research, some Ukrainian authors also paid their scientific attention to a university 
professor's portrait and explained what it means to be a professor at the beginning of the second millennium (V.P. Androushchenko, E.V. Astachova, V. S. Bakirov, V. Osin, V.L. Saveliev, S. Shchudlo, etc.).

Goal and tasks: We'll concentrate on the professorial group of university professors mostly occupying positions at higher educational establishments and acting at the period of last decades of globalization. Our goal will be to find out how university professoriate has changed during globalization era and whether its service to the society acquired political features.This will be done with the help of simulating a political portrait of a university professor and singlingout the identification features and academic positions in the system of public relations in the conditions of globalization.

Our tasks will be:

$\checkmark$ To expose the common features of a general portrait of university professors;

$\checkmark$ To show some basic orientations and preferences in politics of university professors ; $\checkmark$ To dwell upon some tendencies of change in common university professor 's political portrait in globalization era.

$\checkmark$ To draw attention of scientific community, governing bodies of education, heads of higher education institutions to sociopolitical problems of activity of professoriate in the conditions of transformational processes in education during a globalization era

\section{Research methods.}

The article uses quantitative and qualitative methodology approaches. Quantitative data on the globalization tendencies and professoriate educational and political status are analyzed to discover empirically verified patterns. It helps to interpret the information on base of stated purposes. The qualitative data are analyzed both deductively and inductively.

\section{Results of investigation.}

Let's view a notion of a university professor's portrait as a social group of a community, with its features of professional labor, status, typical characteristics in the way of life, behavior, world outlook, relationships in society that reflect the transformations at a turn of two centuries. High I.Q. level, certain ethical standards and democratic moral qualities unite representatives of this academic rank worldwide. Among common features that we can find in this professional group practically in all countries of the globe are: the presence of an academic degree, PHD or doctorate; a position in the university hierarchy, publications and references in foreign and home publishing; efforts to meet the changing demands of higher educational establishments; the necessity of constant appreciation of professors' work by both domestic and international peer community; striving for popularity among students (professors are keen on the results of teaching evaluations); continuous search for opportunities to be on the edge of new technologies, expressing their opinion on urgent political issues in society, etc.

The simulated portrait of a university professor possesses basic characteristic features that became spread in globalized era worldwide. The most common of them are high educational level and confirmed academic degree. For that persons engaged in the professorial work should have a definite level of education. Universities usually offer the standards of qualification and educational level for top positions in different countries. As Altbach says, «the doctor's degree as the obligatory requirement to candidates practically for all academic positions in Australia, Canada, Europe, the USA during the previous century - now becomes the requirement to candidates for positions at research universities everywhere» (Как платят профессорам 2012: 2).

Basic characteristic features in the simulated professor's portrait can't be understood without dwelling upon the impact of globalization on the standards of Universityprofessors' position in the educational system. Globalization introducedmodern electronic technologies into higher education process, new flow of information and ideas, market mechanisms, great shifts in funds, people movement within educational systems in all countries. New patterns of global social and political life and political socialization among professoriate community emerged everywhere as well.

Global market-driven development of higher education in the globalized era resulted intransformationsof some professorial duties that affected mostly the allocation of time andperformed roles. There happened the enlargement of teaching time in professors' teaching loads that gave rise to the appearance of a new kind of a scholar - a teaching academic (TA) who has to combine teaching and research in a new proportion. It has become common practice for a professor to teach several courses. In higher education emphasis was transferred mostly to academic work which included teaching, marking, supervision and administration. Australia, Canada, the United Kingdom and the United Stateswere marked by the rise of TA roles. Besides, professors were 
exposed to the need of acquiring the western standards of teaching in the conditions of inflation and sharp reduction of wages.The appearance of a new type of a teaching academic in the globalized era contributed to the transformation of professoriate profession and subdivided academics into groups with higher teaching loads and fewer perspectives for being engaged in research and with lower teaching loads and more research opportunities.

Globalization demanded from professoriate new skills, the most important was the ability to cope with challenges in mastering the personal computer.Global introduction ofinformation communicative technologies in educational process made the Revolution in the process of education. The professors were in the vanguard of employees for acquiring new computer skills andthe majority of them were able to cope with new demands of information era, thoughsome lagged behind. Modern knowledge in computers' operating was necessary for professors in order to educate the «digital» generation. A high level of computer skills became a must for university professor's labor in globalized era.

Among basic characteristic features that constitute the essence of a simulated university professor's portrait we can name research activity, which acquired some new forms during globalized era. "While following a global model, the call for research-especially in developing countries -has not come with sufficient concomitant of financial support for researchers or improvement of the institutional infrastructure» (Stromquist 2007: 218). The transformations of a university model from multiversity to an entrepreneurial one in the globalized era brought to life the appearance of a new type of scientist, the entrepreneurial scientist or a«professor-entrepreneur».The understanding of a university professor as «entrepreneurial scientist» varies from university to university and depends upon the economic and political development of a state. The critical voices, while analyzing this type of a researcher, point at the deplorable behavior of «professor-entrepreneurs» because of the «usage of belonging to the academic community as a launch pad for profitable activity» (Андрущенко, Савельев 2010: 314).

The above mentioned characteristic features are typical for all professorial communities in the globe. In spite of the fact that the composition of the academy has never been monolithic; it differs in aspirations, hierarchy, conditions of labor, belonging to this or that educational establishment with unequal salaries. Professors have their own rewards, modes of knowledge delivery, they work not only in the sphere of knowledge production, teaching and accountability, but they also act in the sphere of social improvement. They are all united by their position in the global political system and by the existence of their political preferences, attitudes, orientations and political views. The political portrait of a university professor is grounded on the basic characteristic features common worldwide.

In general, the professors are incorporated into the political system of their own countries with the orientation at the «output» (D. Iston) from the political system. They voice their political positions in their research works, while teaching or performing their social functions. Their political views are formed on the interaction of such variables as the ideas of democracy, their income and the prestige of their specialty. The majority of them want societies acting through governments which are capable to resolve the most urgent problems and make the life better for people.

We think that the core of professor's political portrait stems from political views and public attitudes. It's of great importance to define the prevailing political values and political orientations in the professorial portrait. They vary from country to country and depend on political situation, gender, age, traditions, etc. Still we can distinguish adherence to traditional and modern democratic political values, that sometimes become the ground for the critical attitude of professors towards the policy of power institutions in the epoch of globalization. Signing petitions, explaining their political positions in mass media, participating in the activity of political parties, voicing their opinion in different commissions outside the university, etc. represent examples of professor's political position in reference to the political events happened in the globalized society.

Political preferences of professors are rooted in a character of a political regime, form of government, existence or banning democratic rights and freedoms, changeability of ideologies in this or that country, etc.For example, in the west professorsorient mostly to conservative or liberal ideological spectrum that became very popular during globalization era. The number of their followers fluctuated in different decades. «Liberalism was internationalist in the 1930s and isolationist in the 1970s; conservatism made a parallel shift in the other direction» (King, Schlozman, Nie 2009: 79-80). In the second decade of the XX1 
century the USA polls'cited datashow the change in correlation number between professors supporting liberals and conservatives in the ratio of 1 to 6 or even 1 to 28 (Жданов, 2018).

In reference to these data the «problem of politicization arises. Can a university professor teach politics as «political acts»»? Van Dyke, professor of Iowa University states that the politicization of the classroom by the professorwill result and should result in the politicization of the academy by the society. Moreover, the politicization of the classroom by one professor would lead to a rival politicization by another, and so on, until the academy is made into a political community with majorities and minorities, tyrannies and factions, or into rival political communities, with conservative colleges, liberal colleges, and all kinds of political colleges. To some extent such divisions are inevitable and tolerable, and even, in small doses, healthy as a special brand of pluralism. But the degree of politicization recently sought, and the elevation of such politicization to high principle would produce intolerable results (Van Dyke 1997: 103).

Participation in politics belongs to one of the most important features of a simulated portrait that reflects basic orientations and preferencesof university professors. In globalized era we observecases that show some increase of political activity among professoriate. Their representatives replace highest political posts for the society service. For them, according to M. Weber, participation in politics becomes not only calling, but also a profession (Вебер, 1990).

Widely known examplesbelong to American professors who managed to leave their universities for some time andmove to work as political consultants of U.S. Presidents. The governmental posts in the USA were held by such famous political scientists as $\mathrm{Z}$. Brzezinski, G. Kissinger, S. Huntington, F.Fukuyama, etc. Condoleezza Rice, professor of political sciences of Stanford University, the executive rector (Provost) of this prestigious educational institution (1993-1999) was the adviser for national security of the 43rd U.S. President J. Bush (Jr.), and she was also the 41st U.S. President J. Bush (S) adviser for Russia (Ирхин 2019 : 5) .

With globalization growth, recruiting professorial staff or the highest legislative bodies became worldwide practice. Professors began to participate in the supreme organs of power of their countries, first of all, in parliaments more actively. By data, presented by V. Osin, a third of deputies of the lower house of the Swiss parliament possessed scientific degree of Ph.D., and every fifth deputy of the Bundestag in 2011 had doctor' degree. And these figures are compatible to the data referring to the majority of the Post-Soviet states. For example, in Ukraine, according to the estimates of V. Osin, 45,9\% of governors and $35,87 \%$ of heads of regional councils had scientific degrees of the candidate and/or doctor of science (Осин 2014: 41).

But the number of parliamentarians with doctor's academic degrees in different countries is not constant and it is subjected to fluctuations. In globalized era with the expansion of population's participation in politics and emergence of new professional layers (managers, IT experts, bloggers, etc.) in the top echelons of power,the countries of the Central and Eastern Europe experiencethe general tendency of diminishing specific number of «academics» among parliamentarians. «Over the past six legislative terms, the proportion of teachers and professors has declined from some 20 to 12 percent» as pointed by E. Semenova, M. Edinger and $\mathrm{H}$. Best (Semenova, Edinger, Best 2014: 291).

In general, the contraction of professoriate's representatives in the parliaments in the states of Western Europe does not look so sharp and catastrophic. Shortening of the number of professors among MP's deputies is more impressive, for example, in Ukraine. In the Verkhovna Rada of the sixth convocation in 2007 the share of teachers and professors does not exceed 8\% while in 1994 it approached 30\% (Semenova 2012: 546). The Verkhovna Rada of the next convocation, «as of May 30, 2013, stated that 26 People's Deputies of Ukraine with a scientific doctor's degree and 100 with the candidate of science degree were among MP's members» (Матола 2013).In the Verkhovna Rada of the ninth convocation the smaller number of parliamentarians - doctors of science is predicted.

But on grass -root level professors mostly do not belong to the most politically active segments of society. The results of the survey done under the guidance of N. Stromquist state that in the countries studied, university professors - potentially a significant political force - have not manifested themselves as an oppositional voice (Stromquist 2007: 222).

In a globalized era the simulated portrait of a university professoracquired features of adherence to academic freedom, pursuit and development of cosmopolitism as the result of mobility growthamong the members of this 
group of professionals. Professorial mobility, connected with opportunities to participate actively in various programs, trainings, seminars, international conferences, forums, etc., gave professors more freedom to travel, communicate and thus propagate their political views more actively.

At a turn of two centuries academic migration became a prominent feature in the social portrait of a university professor. For some countries it meant «loss of the intellectual capital, or «brain-drain», for others - «the pursuit of minds», that presupposes the usage of intellectual capital for economic development. Many professors migrated to other states thus weakening the intellectual potential of their home countries. Hence different professional associations and international communities became a field of attraction for professor's labor.

On the crossing of notions «mobility» and «migration» we come across the term political migration that presupposes the escape from home country because of persecutions on political convictions. As a rule, changes of frontiers, discrimination of separate groups of the population, wars, revolutions, etc. explain the emergence of this phenomenon. Political migration as an element of global migration reflects the directions of global migratory processes. Consequently, loss of the intellectual capital results from departure from the country of highly educated scientific personnel. Political migration embraces all complex of groups of highly qualified specialists including a professoriate. But in a globalized era it was substituted by the economic migration as the professors all over the world lost some of their material benefits and became mostly the members of the middle class that is subjected to erosion.

\section{Conclusions.}

It is difficult to come to a consensus about common features that characterize the diversity of university professors across the globe. They differ from country to country, from university to university. In globalized era there happened a new attitude towards professors' work, changes in the organization of inside and outside professor's activity, at the university and on the international level. The main tendencies in the change of professoriate' labor due to theimpact of globalization were also rooted in deregulation, privatization and competitiveness.

Globalization has many sides. One of its aspects is the dissemination of knowledge. Professors play a key role in this process. Their respectable and popular academic professions have their peculiarities in various countries and universities. They stem from differentiation among regions, fields of knowledge, chances to receive financing for research and development, opportunities to participate in the competitions to get grants for international programs, possibilities to visit local and/or international conferences, etc. What is important - professors are all united by the work with students at universities and are engaged in knowledge development. These features help us understand why the professors are alike all over the globe.

In order to understand the importance of this professional layer in society better we have built a simulated professor's portrait with universal characteristic features. They constitute the base of a political portrait of a university professor and are connected with changing political values and political orientations. The tendencies of political activity aimed at making political decisions in society level reflectthe growth of professors' service to the needs of society. But still, we can't say that a great bulk of a university professoriate is politically active. At the same time we mark the adherence of professors to academic freedoms in global context.In general, in the XXI century the portrait of a university professor has undergone significant changes not only in roles performed but in political service to society as well. Hence professors' political activity serves as an example for young generation. That's why the political portrait of professoriate might be the subject of future scientific research.

\section{REFERENCES}

Как платят профессорам? Глобальное сравнение систем вознаграждения и контрактов. 2012. (редакция Ф. Альтбах, Л. Райсберг, М. Юдкевич, Г. Андрущак, И. Пачеко ; пер с англ. Е.В. Сивак; Нац. исслед. ун-т «Высшая школа экономики». М.: Изд. дом Высшей школы экономики.

Stromquist N. P. (ed.). 2007. The Professoriate at the Age of Globalization. Rotterdam/Taipei: Sense Publishers.

Андрущенко, В. П, Савельев, В. Л. 2010. Образовательная политика (обзор повестки дня). К.: МП Леся.

King G., Schlozman K., Nie N. H. 2009. The future of political science 100 Perspectives. New York: Taylor \& Francis Group.

Жданов, С. 2018. “Думай за себя: как борьба за социальную справедливость вызвала к жизни движение «темных интеллектуалов". НОЖ URL: https://knife.media/intellectual-dark-web/ (дата звернення: 11.09.2019).

Van Dyke Vernon (ed.). 1997. Teaching Political Science: The Professor and the Polity. Atlantic Highlands, N. J.: Humanities Press. 
Вісник ХНУ імені В. Н. Каразіна, серія «Питання політології», вип. 35, 2019

Вебер, М. 1990. "Политика как призвание и профессия”. 1918. Избранные произведения: пер. с нем. М.: Прогресс: 643-706.

Ирхин, Ю.В. 2019. Парадигмальные основы, школы и этапы развития политической науки CШA. URL: http://old.kpfu.ru/f15/bin_files/9.pdf

Осин, В. [и др.] 2014. Власть и знание на постсоветском пространстве: политический режим, научная степень, идеология и карьера 6 Украине и Молдове. Вильнюс: ЕГУ.

Semenova, E., Edinger, M., Best, H. 2014. Patterns of parliamentary elite recruitment in Central and Eastern Europe. A comparative analysis Parliamentary Elites in Central and Eastern Europe.Recruitment and representations. New York: Routledge: 284-304.

Semenova, E. 2012 (August). Patterns of Parliamentary Representation and Careers in Ukraine 1990-2007. In: East European Politics and Societies.Vol. 26. 3: 538-560.

Матола В.2013.У нинішній Раді засідають 26 докторів наук, 100 кандидатів, 22 професори і понад два десятки доцентів. Тиждень. UA. Вип.№29. 27 червня-16 серпня 2013. URL: http://tyzhden.ua/News/80985

\section{REFERENCES}

Как платят профессорам? Глобальное сравнение систем вознаграждения и контрактов. 2012. (editors F. Altbakh, L. Raisberh, M. Yudkevych, H. Andrushchak, Y. Pacheko ; translation from English E.V. Sivak; National Research Universality "High School of Economics". M .: Publishing. House of the Higher School of Economics (in Russian)

Stromquist N. P. (ed.). 2007. The Professoriate at the Age of Globalization. Rotterdam/Taipei: Sense Publishers.
Andrushchenko V. Savelev V. 2010. Education policy (agenda review).K.: MP Lesya (in Russian)

King G., Schlozman K., Nie N. H. 2009. The future of political science 100 Perspectives. New York: Taylor \& Francis Group.

Zhdanov S. 2018. "Think for yourself: how the struggle for social justice brought to life the movement of "dark intellectuals"". NOZh URL: https://knife.media/intellectual-dark-web/ (in Russian)

Van Dyke Vernon (ed.). 1997. Teaching Political Science: The Professor and the Polity. Atlantic Highlands, N. J.: Humanities Press.

Weber M. 1990. "Politics as a vocation and profession". 1918. Selected Works: translation from germ. M.: Prohress: 643-706. (in Russian)

Yrkhyn $\mathrm{Yu}$. 2019. The paradigmatic foundations, schools and stages of development of political science in the USA. URL: http://old.kpfu.ru/f15/bin_files/9.pdf (in Russian).

Osyn V. [et al] 2014. Power and knowledge in the post-Soviet space: political regime, academic degree, ideology and career in Ukraine and Moldova. Вильнюс: ЕГУ. (in Russian)

Semenova, E., Edinger, M., Best, H. 2014. Patterns of parliamentary elite recruitment in Central and Eastern Europe. A comparative analysis Parliamentary Elites in Central and Eastern Europe.Recruitment and representations. New York: Routledge: 284-304.

Semenova, E. 2012 (August). Patterns of Parliamentary Representation and Careers in Ukraine 1990-2007. In: East European Politics and Societies. Vol. 26. 3: 538-560.

Matola V. 2013. There are 26 Doctors, 100 Candidates, 22 Professors and over two dozen Associate Professors in the current Rada. Tyzhden. UA. Issue №29. 27.06. - 16.08 2013. URL: http://tyzhden.ua/News/80985 (in Ukrainian). 